puzzling anomalies of a species of these genera with an ease and certainty hitherto quite impossible.

One criticism Mr. Woods must allow us to make, if only for the guidance of the editor; that is, that in these days of accurate collecting, it is essential that the name of the collector should be inserted after the name of the locality, whenever known. It would add rery greatly to the value of such a monograph as this to know that Dr. Blackmore, for instance, was responsible for the statement that Ostrea semiplana occurred in the zone of Act. quadratus of East Harnham. In the present case such proof is not forthcoming. We congratulate and thank Mr. Woods for the valuable work he has completed.

\title{
IX.-Bhief Notrces.
}

1. Sogrmern Rronesia.-The Report of the Director of the Geological Survey, Mr. H. B. Maufe, for 1911 (1912), records the wide distribution of tin-bearing rocks; notes that the majority of the productive gold-mines do not lie in the schist-belt as is generally thought, but in a peculiar granitic mass, named the Mont d'Or granite; and refers to the important chrome iron-ore deposits which occur in a mass of serpentine and talc-schist.

There are special reports (1) on the geology of the country around Selukwe, by Messrs. A. E. V. Zealley \& B. Lightfoot, with a general introduction by the Director; (2) on the geology of the Victoria Tin-field, by the Director; (3) on the asbestos quarries, Victoria District, by the Director; (4) on the claims of the Great Sabi Coal Syndicate, Victoria District, by Mr. Lightfoot; (5) on claims pegged for aluminium near Selukwe, by $\mathrm{Mr}$. Zealley; and (6) on a traverse from Gwelo to Bulawayo, by Mr. Zealley. With regard to the asbestos Mr. Maufe observes that it consists of the fibrous form of serpentine, known as 'chrysotile asbestos'.

2. Mereoric Iron from Perrytille, Missodri.-The block, which weighed about $17 \frac{1}{2}$ kilograms, was found in an open field, about three-fourths buried in the soil. It is described by Mr. G. P. Merrill (Proc. U. S. Nat. Museum, xliii, December, 1912), who records, among ordinary constituents, traces of iridium, palladium, platinum, and rutbenium. The author states that so far as he knows this is the first authentic instance of the occurrence of ruthenium in a meteoric iron.

3. Underground Waters of Poitod.-In "Spelunca" (Bulletin et Mémoires de la Société de Spéléologie, ix, September, 1912), Professor Jules Welsch records the results of his detailed studies of the " Hydrologie souterraine du Poitou calcaire", in the Departments of Vienne, Deux Sevres, and Vendée, which together coincide closely with the old province of Poitou. After describing the general physical features and geological structure of the region, he deals in particular with the areas of Jurassic limestones from the Lias to the Corallian, etc. (Rauracien-Séquanien). Water-bearing horizons occur throughout the series, but they are most copious in the Bajocian and Bathonian. The sources of the waters, their circulation as affected by dislocations, folds, faults and fissures, the caverns, swallow-holes, 
underground channels and springs, are very fully described, with remarks on sources of contamination.

4. Iridosmine in the Transvant.-This alloy was discovered several years ago by Mr. A. F. Crosse in the Rand bankets. Its occurrence in the $\mathrm{New}$ Rietfontein Mines is recorded by Mr. C. Baring Horwood (Trans. Geol. Soc. South Africa, xv, 1912), and he describes it as an intimate mixture of iridium and osmium, generally with ruthenium, and sometimes with a little platinum, chromium, gold, and palladium. The metals in the banket reefs, in his opinion, are of secondary origin, having originated as segregations formed by magmatic concentration in the basic eruptive rocks of the mines, and from these dykes they were extracted by the action of superheated gases. Later still, hydrothermal action probably played an important part in concentrating them in the banket reefs.

\section{EFPOFTS AND FROOEFDINGS. \\ I.--The Royal Society.}

March 6, 1913.-Sir Alfred Kempe, Vice-President and Treasurer, in the Chair.

The following communications were read:-

1. "The Evolution of the Cretaceous Asteroidea." By W. K. Spencer. Communicated by Dr. A. S. Woodward, F.R.S.

An endeavour is made to trace the evolution of the Starfish through the whole of the Cretaceous deposits. At the first sight the material appeared to be unpromising, for complete or even fragmentary specimens are rare. It has been found possible, however, to use the isolated marginal plates which are found fairly commonly on weathered chalk surfaces. It is shown that these marginal plates have a shape and ornament characteristic of each distinct species. The species may be arranged in lineages, and the examination of large collections made by English and Continental workers make it feasible to trace the life-history of most of the lineages. Each lineage shows definite stages of advance (elaboration) followed by stages of regression. Occasionally a lineage will re-elaborate after passing through the regression stages ('rhythmic' or 'periodic' variation). Elaboration and regression are closely parallel in the lineages. They consist of changes in the size, the height, and the character of the ornament of the plates.

Variation as shown, both through measurements and by general examination, is, in general, of the 'continuous' type. Discontinuous variations ('saltations') are known, but they appear to be relatively of little importance. The measurements also show (1) that there is close connexion between the general vitality of the race, as shown by its range of variability, and the rhythmic phases alluded to above; (2) that the rate of elaboration is affected by environment.

It has not been found possible to show that selection plays any predominant part in the evolution of the lineages, and it is suggested that inborn racial character is the predominant influence in causing modification. 